\title{
EXPLORATION ON THE EFFICIENCY OF CONSTRUCTION PLANT AND EQUIPMENT MAINTENANCE MANAGEMENT SYSTEM BY USING COMPUTERIZED MAINTENANCE MANAGEMENT SYSTEM (CMMS).
}

\author{
${ }^{1}$ Mashanim Mahazir*, ${ }^{2}$ Fekhime Shadkam \\ ${ }^{1}$ Department of Quantity Surveying, \\ Faculty Engineering \& The Built Environment, \\ SEGi University \\ *mashanim@segi.edu.my TEL:6036145 3125
}

\begin{abstract}
In the construction industry plant and equipment one of the important and main sources is to increase productivity of the project. To keep available the plant and equipment need all of technical, administrative, managerial action during the whole life cycle of the project. The study investigates about issue of plant and equipment maintenance management in Malaysian Construction Companies. The aim of this research paper is to improve the efficiency of plant and equipment maintenance management in Selangor construction industry by using Computerize Maintenance Management System (CMMS). The initial stage of the study involved comprehensive literature reviews to gather the data about importance of maintenance, previous implemented maintenance system and types of maintenance system as well as information about Computerize Maintenance Management System (CMMS). Quantitative research approach was adopted through questionnaire surveys. The analysis method is mainly derived from descriptive analysis. Thus, this paper explored the potential application to reduce total downtime and failure of plant and equipment by improving the effectiveness of maintenance management system. This system is computer based program simplifies and decease the duration of finding fault compare to the presently used paper-based reporting.
\end{abstract}

Keywords: Computerized maintenance Management System (CMMS), plant and equipment

\section{Introduction}

"A proper analysis of maintenance records in a company can provide, as an outcome, the information to serve as an input in the process of maintenance policy optimization" ( Ma'rquez 
\& Herguedas 2004 ). However, a more easier than that, data analysis methods can offer clear understanding about failures performance and maintenance managers can straight away benefits from that information to carry out their day-to-day actions.

Thus modern construction project managers must, strongly follow the most efficient maintenance system of the equipment work to company productivity and therefore company continued existence are to be guaranteed.

Nevertheless, the construction company's plant and equipment can be classified into two clear groups as following:

- Firstly- are equipment, which remain largely within the limitations of the construction site.

- Secondly- are machines, which transport materials to the site and from the site.

The range of plant to be found in the industry is wide and varied, as can be seen from the following list of items: pile-driving machinery, demolition plant, tower crane, concrete ready mixer, excavator, pump, scaffold, lifting, dumper, bull-dozer, and compressor and power-hand tools. These plant and equipment in construction industry a Builder would use in the course of normal construction work.

Any of this category a plant and equipment item includes plant managers require to record and manage plant data. If a plant managers or any responsible personal short of such data, the supply of plant performance might be not easy if not impossible to find out. This research paper conducted to provide ideas about how the effective maintenance management can provide important information to improve current maintenance process in a company.

\section{Research method}

The study was conducted in Selangor on way to improve maintenance management. Qualitative and quantitative methods were used to conduct the research. All data obtained were analyzed using SPSS software. Data was examined by using descriptive analysis.

\section{Data analysis and findings}

Realibility scale

Table 1 represents the Cronbach's alpha $(\alpha)$ value for each measure. It should be noted that all the negative worded items in the questionnaire were first be reversed coded before the items 
were submitted for reliability test. The item with the lowest corrected item-to-total correlation was removed until the. 7 level was met. All measures have Cronbach's alpha of greater than 0.7, thus, these measures satisfy the internal reliability criterion. The 10 multi-variable factors used in this study have gone through several successive reliability testing treatments. The statistical information for seventeen variables shows that Cronbach's alpha score are at least 0.710 (Failure causes) which means the entire construct are deemed to have adequate reliability.

Table 1. Causes of failure

\begin{tabular}{lcc}
\hline \multicolumn{1}{c}{ Variable } & N. of Items & Cronbach's Alpha \\
\hline $\begin{array}{l}\text { Causes of poor or lack of } \\
\text { the plant and equipment }\end{array}$ & 6 & .872 \\
$\begin{array}{l}\text { Plant and equipment fail } \\
\text { to fulfill its functions }\end{array}$ & 2 & .820 \\
\hline $\begin{array}{l}\text { Functional failure } \\
\text { Failure causes }\end{array}$ & 4 & .720 \\
$\begin{array}{l}\text { Consequences of each } \\
\text { failure }\end{array}$ & 4 & .710 \\
Prevent or predict failure & 4 & .730 \\
$\begin{array}{l}\text { Type of action } \\
\text { Period of maintenance }\end{array}$ & 4 & .721 \\
\hline $\begin{array}{l}\text { Preventive actions } \\
\text { Failure effects to the } \\
\text { project }\end{array}$ & 3 & .792 \\
\hline
\end{tabular}

Descriptive statistic analysis.

Descriptive statistics are used to explore the data collected, and summarised and describe those data. Pallant (2007) stated that descriptive statistic is aimed at depicting the different attributes of data, verifying any violation of the principal assumptions for the statistical methods to be used in the study, and addressing particular research questions. In this study, the descriptive statistics are undertaken using central tendency and variation statistics such as means, and ranges.

\subsection{The poor or lack plant and equipment management in Selangor, Malaysia}

This section discusses about the data analysis and findings of causes of poor or lack plant and equipment management in Selangor, Malaysia. This section provides ten objective, poor or 
lack of the plant and equipment, plant and equipment fail to fulfill its functions, functional failure, failure causes, and consequences of each failure, prevent or predict failure, Type of action, Period of maintenance, preventive actions, and Failure effects to the project.

Table 2. Causes of por or lack if plant and equipment management

\begin{tabular}{|c|c|c|c|c|c|c|c|c|}
\hline Item & SD & D & $\mathbf{N}$ & $\mathbf{A}$ & SA & M & Median & Mode \\
\hline $\begin{array}{l}\text { Poor or } \\
\text { inappropriate } \\
\text { operation }\end{array}$ & 2,5 & 5.0 & 73.5 & 45.0 & 10.0 & 3.55 & 4.00 & 4.00 \\
\hline Lack of training & 2.5 & 7.5 & 27.5 & 47.5 & 15.0 & 3.65 & 4.00 & 4.00 \\
\hline Lack of experience & 5.0 & 2.5 & 17.5 & 52.5 & 22.5 & 3.85 & 3.00 & 3.00 \\
\hline $\begin{array}{l}\text { Impact of data } \\
\text { collection }\end{array}$ & 2.5 & 20.0 & 47.5 & 25.0 & 5.0 & 3.10 & 3.00 & 3.00 \\
\hline $\begin{array}{l}\text { Oil samples for } \\
\text { analysis }\end{array}$ & 2.5 & 22.5 & 45.0 & 25.0 & 5.0 & 3.08 & 3.50 & 3.00 \\
\hline $\begin{array}{l}\text { Maintenance } \\
\text { selection }\end{array}$ & 10.0 & 40.0 & 42.5 & 5.0 & 2.5 & 3.95 & 4.00 & 4.00 \\
\hline
\end{tabular}

Frequency distribution and measurements in the form of means for the 6 variables are reflected in Table 2. It can be observed that the mean scores for Maintenance selection (3.9), Lack of experience (3.85), Lack of training (3.65), Poor or inappropriate operation (3.55) are very high. Meanwhile, the Impact of data collection (3.10) and Oil samples for analysis (3.08) are moderate.

Table 3. Plant and equipment to fulfill its function

\begin{tabular}{lcccccccc}
\hline \multicolumn{1}{c}{ Item } & SD & D & N & A & SA & M & Median & Mode \\
\hline $\begin{array}{l}\text { Functional failure } \\
\text { by Operators }\end{array}$ & 5.0 & 7.5 & 15.0 & 45.0 & 27.5 & 3.82 & 4.00 & 4.00 \\
$\begin{array}{l}\text { Potential failure } \\
\text { by Maintenance } \\
\text { personnel }\end{array}$ & 5.0 & 27.5 & 15.0 & 47.5 & 5.0 & 3.20 & 4.00 & 4.00 \\
\hline
\end{tabular}

The means for the two variables are presented in Table 3. It can be observed that the mean scores of plant and equipment fail to fulfill its functions variables which include Functional failure by Operators and Potential failure by Maintenance personnel have indicated a high level and moderate with mean score (3.82 and 3.21). 
Table 4. Functional failure

\begin{tabular}{lcccccccc}
\hline \multicolumn{1}{c}{ Item } & SD & D & N & A & SA & M & Median & Mode \\
\hline $\begin{array}{l}\text { Some equipment } \\
\text { parts }\end{array}$ & 2.5 & 2.5 & 25.0 & 55.0 & 15.0 & 3.77 & 4.00 & 4.00 \\
$\begin{array}{l}\text { Some human } \\
\text { activities }\end{array}$ & 2.5 & 2.5 & 30.0 & 47.5 & 17.5 & 3.75 & 4.00 & 4.00 \\
$\begin{array}{l}\text { Improper } \\
\text { operation }\end{array}$ & 2.5 & 7.7 & 20 & 45.0 & 25.0 & 3.82 & 4.00 & 4.00 \\
$\begin{array}{l}\text { Improper } \\
\text { maintenance }\end{array}$ & 2.5 & 15.0 & 27.5 & 40.0 & 15.0 & 3.50 & 4.00 & 4.00 \\
\hline
\end{tabular}

The results in Table 4 show that the means are high for improper operation (3.82), some equipment parts (3.77), some human activities (3.75), and Improper maintenance (3.50).

Table 5. Failure causes

\begin{tabular}{|c|c|c|c|c|c|c|c|c|}
\hline Item & SD & D & $\mathbf{N}$ & $\mathbf{A}$ & SA & $\mathbf{M}$ & Median & Mode \\
\hline $\begin{array}{l}\text { Effect to } \\
\text { Downtime of plant } \\
\text { and equipment }\end{array}$ & 0 & 10.0 & 25.0 & 42.5 & 22.0 & 3.77 & 4.00 & 4.00 \\
\hline $\begin{array}{l}\text { Failure to perform } \\
\text { their normal } \\
\text { Duties }\end{array}$ & 0 & 7.5 & 32.5 & 42.5 & 17.5 & 3.70 & 4.00 & 4.00 \\
\hline $\begin{array}{l}\text { Effects to Project } \\
\text { cost }\end{array}$ & 0 & 5.0 & 17.5 & 50.0 & 27.5 & 4.00 & 4.00 & 4.00 \\
\hline $\begin{array}{l}\text { Effects to Project } \\
\text { duration }\end{array}$ & 2.5 & 2.5 & 35.0 & 35.0 & 25.0 & 3.76 & 4.00 & 3.00 \\
\hline
\end{tabular}

The results in Table 5 show that the means are high for Effects to Project cost (4.00), Effect to Downtime of plant and equipment (3.77), Effects to Project duration (3.76), and Failure to perform their normal Duties (3.70). 
Table 6. Consequences of failure

\begin{tabular}{lcccccccc}
\hline \multicolumn{1}{c}{ Item } & SD & D & N & A & SA & M & Median & Mode \\
\hline $\begin{array}{l}\text { Goals for } \\
\text { profitability }\end{array}$ & 2.5 & 12.5 & 47.5 & 22.5 & 15.0 & 3.35 & 4.00 & 3.00 \\
$\begin{array}{l}\text { Safety performance } \\
\begin{array}{l}\text { Environmental } \\
\text { performance }\end{array}\end{array}$ & 0 & 7.5 & 60.0 & 25.0 & 7.5 & 3.32 & 4.00 & 3.00 \\
$\begin{array}{l}\text { Operational } \\
\text { performance }\end{array}$ & 0 & 0 & 27.5 & 50.0 & 22.5 & 3.95 & 4.00 & 4.00 \\
\hline
\end{tabular}

The means for the four variables are presented in Table 6 . It can be observed that the mean scores of consequences of each failure variables which include Operational performance and Environmental performance have indicated a high level with mean score (3.95 and 3.60). Also, the safety performance and goals for profitability (3.35 and 3.32).

Table 7. To prevent or predict failure

\begin{tabular}{lcccccccc}
\hline \multicolumn{1}{c}{ Item } & SD & D & N & A & SA & M & Median & Mode \\
\hline $\begin{array}{l}\text { Scheduled } \\
\text { inspection to } \\
\text { find any } \\
\text { potential failure } \\
\text { (by maintenance } \\
\text { personals) }\end{array}$ & 0 & 5.0 & 27.5 & 50.0 & 17.5 & 3.80 & 4.00 & 4.00 \\
$\begin{array}{l}\text { Scheduled } \\
\text { rework some } \\
\text { specified age }\end{array}$ & 0 & 7.5 & 35.0 & 42.5 & 15.0 & 3.65 & 4.00 & 4.00 \\
limit & & & & & & & & \\
$\begin{array}{l}\text { Scheduled } \\
\text { discard work to } \\
\text { some specific life }\end{array}$ & 0 & 7.5 & 50.0 & 32.5 & 10.0 & 3.45 & 4.00 & 3.00 \\
limit & & & & & & & \\
$\begin{array}{l}\text { Scheduled } \\
\text { inspection to } \\
\text { find any } \\
\text { functional } \\
\text { failure (by } \\
\text { operators) }\end{array}$ & 0 & 0 & 17.5 & 57.5 & 25.0 & 4.07 & 4.00 & 4.00 \\
\hline
\end{tabular}


The results in Table 7 showed that the means are high for scheduled inspection to find any functional failure (by operators) (4.00), scheduled inspection to find any potential failure (by maintenance personals) (3.80), and scheduled rework some specified age limit (3.65). In contrast, the means are moderate for while scheduled discard work to some specific life limit (3.45).

Table 8. Type of action

\begin{tabular}{lcccccccc}
\hline \multicolumn{1}{c}{ Item } & SD & D & N & A & SA & M & Median & Mode \\
\hline $\begin{array}{l}\text { Redesigned to that } \\
\text { an acceptable level } \\
\text { of rick }\end{array}$ & 5.0 & 10.0 & 35.0 & 42.0 & 7.5 & 3.37 & 4.00 & 4.00 \\
$\begin{array}{l}\text { Failure approach } \\
\text { which consequence } \\
\text { reduction tasks } \\
\text { make less impact to } \\
\text { failure }\end{array}$ & 2.5 & 7.5 & 50.0 & 37.5 & 2.5 & 3.30 & 4.00 & 3.00 \\
$\begin{array}{l}\text { Change plant and } \\
\text { equipments to new }\end{array}$ & 5.0 & 12.5 & 40.0 & 37.5 & 5.0 & 3.25 & 4.00 & 4.00 \\
\hline
\end{tabular}

Frequency distribution and measurements in the form of means and standards deviations for the three types of action variables are reflected in Table 8. It can be observed that the mean scores for redesigned to that an acceptable level of rick (3.37), failure approach which consequence reduction tasks make less impact to failure (3.30), and change plant and equipment's to new (3.25) are moderate. 
Table 9. Period of maintenance

\begin{tabular}{lcccccccc}
\hline \multicolumn{1}{c}{ Item } & SD & D & N & A & SA & M & Median & Mode \\
\hline Few days & 5.0 & 12.5 & 22.5 & 45.0 & 15.0 & 4.62 & 4.00 & 4.00 \\
One week or less & 2.5 & 12.5 & 12.5 & 67.5 & 5.0 & 3.60 & 4.00 & 4.00 \\
Few weeks & 5.0 & 17.5 & 35.0 & 35.0 & 7.5 & 3.22 & 4.00 & 4.00 \\
$\begin{array}{l}\text { One month or } \\
\text { less }\end{array}$ & 12.5 & 25.0 & 40.0 & 20.0 & 2.5 & 2.75 & 4.00 & 4.00 \\
\hline
\end{tabular}

The means for the four periods of maintenance variables are presented in Table 9. It can be observed that the mean scores of period of maintenance which include few days and One week or less have indicated a high level with mean score (4.62 and 3.60). Also, few weeks and One month or less (3.22 and 2.75) are moderate.

Table 10. Preventive action

\begin{tabular}{|c|c|c|c|c|c|c|c|c|}
\hline Item & SD & D & $\mathbf{N}$ & $\mathbf{A}$ & SA & M & Median & Mode \\
\hline Everyday checklist & 5.0 & 17.5 & 25.0 & 45.0 & 7.5 & 3.32 & 4.00 & 4.00 \\
\hline $\begin{array}{l}\text { Functional } \\
\text { inspection by } \\
\text { operator }\end{array}$ & 0 & 5.0 & 15.0 & 55.0 & 25.0 & 4.00 & 4.00 & 4.00 \\
\hline $\begin{array}{l}\text { Potential } \\
\text { inspection by } \\
\text { maintenance } \\
\text { department }\end{array}$ & 2.5 & 5.0 & 22.5 & 55.0 & 15.0 & 3.75 & 4.00 & 4.00 \\
\hline Test & 0 & 2.5 & 35.0 & 47.5 & 15.0 & 3.75 & 4.00 & 4.00 \\
\hline Data analysis & 5.0 & 0 & 40.0 & 42.5 & 12.5 & 3.57 & 4.00 & 4.00 \\
\hline
\end{tabular}

The results in Table 10 show that the means are high for functional inspection by operator (4.00), potential inspection by maintenance department (3.75), test (3.75), and data analysis (3.57). In contrast, the means are moderate for while everyday checklist (3.32).

Table 11. Failure effects to project

\begin{tabular}{lcccccccc}
\hline \multicolumn{1}{c}{ Item } & SD & D & N & A & SA & M & Median & Mode \\
\hline $\begin{array}{l}\text { Increase project } \\
\text { cost }\end{array}$ & 0 & 0 & 17.5 & 50.0 & 32.5 & 4.15 & 4.00 & 4.00 \\
$\begin{array}{l}\text { Delay project } \\
\text { completion }\end{array}$ & 0 & 2.5 & 32.5 & 37.5 & 27.5 & 3.90 & 4.00 & 4.00 \\
\hline
\end{tabular}




\begin{tabular}{lcccccccc}
\hline $\begin{array}{l}\text { Loss company } \\
\text { good performance } \\
\text { No effects }\end{array}$ & 0 & 10.0 & 47.5 & 30.0 & 12.5 & 3.45 & 4.00 & 3.00 \\
\hline
\end{tabular}

The means for the four failure effects to the project variables are presented in Table 11. It can be observed that the mean scores of Failure effects to the project which include Increase project cost and Delay project completion have indicated a high level with mean score (4.15 and 3.90). Loss of company good performance and No effects (3.45 and 2.30) are moderate.

\subsection{Improving the efficiency of plant and equipment maintenance management system} (CMMS) in construction industry in Selangor, Malaysia

This section aimed to identify the improvement of efficiency of plant and equipment maintenance management system CMMS in construction industry of Selangor, Malaysia. Table 12 showed the result on how to improve the efficiency of plant and equipment management. 
Table 12. To improve the efficiency of plant and equipment maintenance management system CMMS in construction industry in Selangor.

\begin{tabular}{|c|c|c|}
\hline Items & Answer & Percentage \\
\hline \multirow{2}{*}{$\begin{array}{l}\text { Willingness to improve the } \\
\text { efficiency of plant and equipment } \\
\text { maintenance }\end{array}$} & Yes & 90 \\
\hline & No & 10 \\
\hline \multirow{2}{*}{$\begin{array}{l}\text { Awareness in Computerized } \\
\text { Maintenance Management System } \\
\text { (CMMS }\end{array}$} & Yes & 40 \\
\hline & No & 60 \\
\hline \multirow{2}{*}{$\begin{array}{l}\text { Implementation of CMMS in } \\
\text { Malaysia }\end{array}$} & Yes & 27.5 \\
\hline & No & 20.0 \\
\hline \multirow{2}{*}{$\begin{array}{l}\text { The need of maintenance } \\
\text { management system for plant and } \\
\text { equipment }\end{array}$} & Yes & 57.5 \\
\hline & No & 42.5 \\
\hline \multirow{7}{*}{$\begin{array}{l}\text { Company acquires maintenance } \\
\text { management system for plant and } \\
\text { equipment }\end{array}$} & Breakdown & 47.5 \\
\hline & Failure to Data analysis & 30.0 \\
\hline & Failure tracking system & 12.5 \\
\hline & Safety plans Failure & 2.5 \\
\hline & $\begin{array}{l}\text { Failure in Preventive } \\
\text { maintenance }\end{array}$ & 5.0 \\
\hline & $\begin{array}{l}\text { Failure in Corrective } \\
\text { maintenance }\end{array}$ & 2.5 \\
\hline & Failure in Recording & 0.0 \\
\hline \multirow{3}{*}{$\begin{array}{l}\text { Are you willing to improve } \\
\text { Maintenance Management } \\
\text { System? }\end{array}$} & Manpower & 35.0 \\
\hline & $\begin{array}{l}\text { To reduce cost of } \\
\text { maintenance }\end{array}$ & 50.0 \\
\hline & $\begin{array}{l}\text { To reduce maintenance } \\
\text { duration }\end{array}$ & 15.0 \\
\hline \multirow{4}{*}{$\begin{array}{l}\text { Adaptation of simple and effective } \\
\text { maintenance management system } \\
\text { Company improvement the } \\
\text { reliability of plant and equipment } \\
\text { and to reduce maintenance }\end{array}$} & Yes & 53.5 \\
\hline & No & 47.5 \\
\hline & Yes & 70.0 \\
\hline & No & 30.0 \\
\hline \multirow{4}{*}{$\begin{array}{l}\text { CMMS to increase plant and } \\
\text { equipment performance } \\
\text { CMMS to increase project } \\
\text { performance }\end{array}$} & Yes & 65.0 \\
\hline & No & 35.0 \\
\hline & Yes & 70.0 \\
\hline & No & 30.0 \\
\hline
\end{tabular}




\section{Conclusion and recommendation}

Conclusion

The findings of the diverse components of this study were synthesized with respect to the research objectives. Consequently, the summary of the findings reflected that the research objectives were achieved.

\section{Recomendation}

- It is recommended to find strategy for improving the existing plant instead of getting future plants right, and makes junior staff responsible for assessing failure criticalities.

- It is recommended to find strategy for seeks how to avoid the requirement of a maintenance system based truly on reliability for accurate and complete data analyzed in a modern maintenance management information system (MMIS).

- It is recommended to how decrease project cost, poor quality and extended project time, that's included:

- Emergency measures - risk of health, more downtime,

- $\quad$ Risk of safety operating plant and equipment,

- Reduced productivity,

- Delay of program- possible losses of project, probably losses of future projects

- It is recommended computer program (CMMS) for Construction Management and Engineering students to learn as one of subject

- CMMS recommended to government parties (CIDB, JKR and etc.) to train construction maintenance management personals.

\section{Acknowledgement}

The authors would to thank Segi University Kota Damansara for the opportunity given to not forgetting friends and family throughout completing the paper. 


\section{References}

1. P.B. Ahamed Mohideen, M. Ramachandran, Rajam Ramasamy Narasimmalu, (2011) "Construction plant breakdown criticality analysis - part 1:UAE perspective", Benchmarking: An International Journal, Vol. 18 Iss: 4, pp.472 - 489

2. Crespo Márquez, A. and Sánchez Herguedas, A. (2004). Learning about failure root

3. causes through maintenance records analysis. Journal of Quality in Maintenance Engineering, Volume 10, Number 4, pp. 254-262.

4. David J. Edwards, Junli Yang, Ruel Cabahug, Peter E.D. Love, (2005) "Intelligence and maintenance proficiency: an examination of plant operators", Construction Innovation, Vol. 5 Iss: 4, pp.243 - 254

5. Pallant, J. (2007). SPSS survival manual - A step by step guide to data analysis using SPSS for windows (3rd ed.). Maidenhead: Open University Press.

6. Shamsuddin Ahmed, Masjuki Hj. Hassan, Zahari Taha, (2005) "TPM can go beyond maintenance: excerpt from a case implementation", Journal of Quality in Maintenance Engineering, Vol. 11 Iss: 1, pp. $19-42$

7. David J. Edwards, Gary D. Holt, Barry Robinson, (2002) "An artificial intelligence approach for improving plant operator maintenance proficiency", Journal of Quality in Maintenance Engineering, Vol. 8 Iss: 3, pp. $239-252$

8. P.B. Ahamed Mohideen, M. Ramachandran, (2014) "Strategic approach to breakdown maintenance on construction plant - UAE perspective", Benchmarking: An International Journal, Vol. 21 Iss: 2, pp. $226-252$

9. Basim Al-Najjar, Imad Alsyouf, (2000) "Improving effectiveness of manufacturing systems using total quality maintenance", Integrated Manufacturing Systems, Vol. 11 Iss: 4, pp.267 - 276

10. Shyong Wai Foon, Milé Terziovski, (2014) "The impact of operations and maintenance practices on power plant performance", Journal of Manufacturing Technology Management, Vol. 25 Iss: 8, pp. $1148-1173$ 
11. Helen Lingard, Tracy Cooke, Ehsan Gharaie, (2013) "The how and why of plant-related fatalities in the Australian construction industry", Engineering, Construction and Architectural Management, Vol. 20 Iss: 4, pp. $365-380$

12. Alistair Gibb, Sophie Hide, Roger Haslam, Diane Gyi, Trevor Pavitt, Sarah Atkinson, Roy Duff, (2005) "Construction tools and equipment - their influence on accident causality", Journal of Engineering, Design and Technology, Vol. 3 Iss: 1, pp.12-23

13. Sudhir Kumar Singh, Vijay Kumar Bajpai, (2013) "Estimation of operational efficiency and its determinants using DEA: The case of Indian coal-fired power plants", International Journal of Energy Sector Management, Vol. 7 Iss: 4, pp.409 - 429 